\title{
The impact of dredging of a small lowland river on water beetle fauna (Coleoptera)
}

\author{
Piotr DĄBKOWSKI, ${ }^{1}$ Paweł BUCZYŃSKI,${ }^{2}$ Andrzej ZAWAL,${ }^{1 *}$ Edyta STĘPIEŃ,,${ }^{3}$ Edyta BUCZYŃSKA,${ }^{4}$ \\ Robert STRYJECKI, ${ }^{4}$ Stanisław CZACHOROWSKI, ${ }^{5}$ Przemysław SMIETANA,${ }^{6}$ Magdalena SZENEJKO ${ }^{6}$
}

\begin{abstract}
${ }^{1}$ Department of Invertebrate Zoology and Limnology, University of Szczecin, Wąska 13, 71-415 Szczecin; ${ }^{2}$ Department of Zoology, Maria Curie-Skłodowska University, Akademicka 19, 20-033 Lublin; ${ }^{3}$ Department of Plant Taxonomy and Phytogeography, University of Szczecin, Wąska 13, 71-415 Szczecin; ${ }^{4}$ Department of Zoology, Animal Ecology and Wildlife Management, University of Life Sciences, Akademicka 13, 20-033 Lublin; ${ }^{5}$ Department of Ecology and Environmental Protection, Faculty of Biology and Biotechnology, University of Warmia and Mazury in Olsztyn, Plac Lodzki 3, 10-727 Olsztyn; ${ }^{6}$ Deparment of Ecology and Environmental Protection, University of Szczecin, Wąska 13, 71-415 Szczecin, Poland
\end{abstract}

*Corresponding author: zawal@univ.szczecin.pl

\begin{abstract}
Using the example of a regulated stretch of the River Krapiel (NW Poland), an analysis of the impact of dredging on the aquatic beetle (Coleoptera) fauna was made. After dredging the beetle fauna became markedly poorer quantitatively and had lower species diversity. Moreover, the qualitative composition and dominance structure were highly transformed. However, species number and diversity increased rapidly and were restored within just half a year. The structure of the restored fauna was most strongly influenced by vegetation, flow velocity and bottom sediment composition. The first to colonize the river were eurytopic beetles and species typical of small water bodies, which had significant refuges in the form of fish ponds bordering on the river; these species dominated the assemblage throughout the study period. Rheophiles with less dispersal power appeared later, and finally rheobionts, in low numbers but occupying an increasing number of sampling sites.
\end{abstract}

Key words: River regulation; biodiversity; rheophilous species; stagnophilous species; environmental changes.

Received: May 2015. Accepted: April 2016.

\section{INTRODUCTION}

Rivers are among the most transformed aquatic ecosystems; human impact, escalating on a local scale, is manifested as regulation of river channels, hydrotechnical structures, water withdrawal, and increasing contamination and eutrophication associated with changes in the utilization of catchment areas. These transformations have a significant effect on the biodiversity of river fauna and flora (Allan, 1995; Cavailléa et al., 2013; Szlauer-Łukaszewska and Zawal, 2014; Stępień et al., 2015a, 2015b; Zawal et al., 2015, 2016a, 2016b). Typical regulation procedures include dredging of sediment and the removal of littoral vegetation and obstructions in the form of trees and branches in order to increase water flow within the river channel. This can be presumed to have a substantial impact on the composition and functioning of biocoenoses, as numerous essential features of the environment are altered, including water flow velocity, the composition and structure of bottom sediment, availability of light, and the abundance and spatial structure of vegetation. It also has a direct impact by removing organisms from the environment together with sediment and plants (Aldridge, 2000). Other potential dangers directly associated with dredging include an increase in the amount of suspended matter in the part of the river where the works are carried out, and in some cases a decrease in oxygen concentration and an increase in the trophic status and contamination of the water via resuspension of bottom sediment containing toxic substances, particularly in the lower stretches of rivers and their estuaries that have been subject to substantial human impact (de Jonge, 2000; Phelps, 2001). Dredging should thus be considered a type of anthropogenic disturbance initially leading to a decrease in the species diversity and abundance of the benthos, followed by restoration of the original community or a similar one as a consequence of recolonization processes, whose effectiveness depends on a number of ecological factors, as well as on the biological characteristics of the individual taxonomic groups composing it (Niemi et al., 1990; Yount and Niemi, 1990; Aldridge, 2000; Wilber and Clark, 2007). Significantly, this is a very common procedure: in Poland, including West Pomerania, where the study was conducted, as much as half of the length of rivers and canals has undergone dredging. Dredging is thus a typical anthropogenic disturbance in river biocoenoses and knowledge of its effect on the assemblages of organisms forming them is crucial both for scientific research and for the planning and implementation of measures aimed at protecting the natural environment. 
While a number of studies have dealt with the Coleoptera fauna inhabiting various types of river ecosystems (Kordylas, 1990; Richoux, 1994; Kowalik and Buczyński, 2003; Biesiadka and Pakulnicka, 2004; Eyre et al., 2005; Pakulnicka and Zawal, 2007), there has been little research focused on the formation of beetle assemblages and their habitat preferences depending on selected characteristics of lotic environments. Significant environmental factors influencing the formation of Coleoptera fauna in watercourses include the type of bottom sediment, vegetation coverage and type, flow, water depth, $\mathrm{pH}$, and even the amount of suspended solids and conductivity, which reflects how the catchment is utilized (Eyre et al., 1993, 2005; Sanderson et al., 2005; Miserendino and Archangelsky, 2006; Pakulnicka and Nowakowski, 2012; Sarr et al., 2013). Most of these parameters are altered as a result of regulation works, although the extent of the changes and the duration of their effects vary depending on the factor. The effect of these changes on the qualitative and quantitative structure of beetle communities inhabiting the river is unknown. The direction of the formation of these communities is all the more difficult to determine because they are re-formed in conditions of overlapping modifications of environment - earlier regulation of river and later disturbances caused by dredging work. The literature dealing with the effect of dredging on benthic fauna does not provide clear indications of the direction and duration of these changes. Most studies (van Dolah et al., 1984; Aldridge, 2000; Lewis et al., 2001; Ohimain et al., 2005) indicate a decrease in the abundance of macrofauna and changes in species composition and dominance structure, but in varying degrees, at times even minimal and limited to certain biocoenotic indicators (McCabe et al., 1998). Hence the aim of the study was to determine the effect of changes in selected environmental parameters induced by dredging on the abundance, composition and dominance structure of the Coleoptera fauna inhabiting a river, putting forth the hypothesis that the work conducted causes substantial modifications, including a decrease in the abundance and biodiversity of Coleoptera fauna.

A separate and little researched question is the ability of Coleoptera fauna to recolonize new, transformed habitats in a dredged river. While adequate data on this topic is lacking, some studies (Richoux, 1994; Ribera and Vogler, 1999; Biesiadka and Pakulnicka, 2004; Sanderson et al., 2005) suggest that eurytopic species associated with neighboring lentic water bodies and having substantial dispersal capability for evolutionary reasons will colonize available habitats more effectively than lotic species adapted for permanent environments and having lower migratory capacity. Hence one of the aims of the study is to verify this hypothesis.

\section{Study area}

The River Krapiel is a tributary of the River Ina. The segment studied (coordinates N: 53०25'17.38”; E:

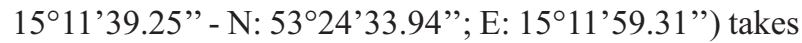
the form of a regulated channel 6-8 $\mathrm{m}$ wide, running alongside fish ponds (Fig. 1). In the studied river section and above it there are no point sources of pollution. Before the dredging the river bed was densely overgrown with macrophytic vegetation, mainly Phragmites australis (Cavanilles) Trinius ex Steudel, 1840, and the bottom was covered with a thick layer of mud. The intervention involved cleaning out the river bed by removing of mud and vegetation covering it using an excavator with a dredge operating from the river bank. The dredging was carried out in December 2008. After the dredging, the Krąpiel retained its previous width. All of the rushes and macrophytic vegetation were removed from the river bed (except for the segment under the bridge, which was left untouched). In addition, a $5 \mathrm{~m}$ strip of rushes and willow shrubs were removed on both sides of the river, leaving only isolated trees (alders and willows). The spoil was deposited on the banks in the form of excavated sediment. Sediment from the river was removed to such a level as not to interfere with the natural slope of the river bed, to avoid the formation of depressions filled with stagnant water. This resulted in the removal of about $80 \%$ of the mud that had previously filled the river bed, as well as the removal of silt and sand from some places. The patency of the channel increased $20-50 \%$ in places that were not previously overgrown and $80 \%$ in places that had been overgrown with reeds (Phragmites).

Six sampling stations were established on a segment of the river about $3 \mathrm{~km}$ long (Fig. 1). Two stations were situated at undredged locations (control stations) - D0 upstream from the dredged segment and D4 near the bridge, and the remaining stations were at dredged sites -D1, D2, D3 and D5. At each station, samples were taken from the lentic (stagnant) and the lotic (drift) zone (Tab. 1). The former included shallow stretches, in some places strongly overgrown with plants, and the river bottom contained a layer of deoxygenated sediment whose surface was covered with detritus. The latter included stretches devoid of vegetation, with higher proportions of sand and gravel in the sediments. Additional samples were collected from fish ponds (four stations).

\section{METHODS}

The investigation of water beetles in the River Krapiel was carried out in July 2008, before the dredging, and from April to August 2009, after the dredging. One series of samples was collected from the sampling stations before the dredging, and after the dredging material was collected 5 times in successive months. 
The samples were taken using a hand dredge with 50 $\mu \mathrm{m}$ mesh net from a $1 \mathrm{~m}^{2}$ area marked by a metal square frame. The beetles collected were preserved in $75 \%$ alcohol. Taking into account all sites, the following dominance classes were established: eudominants $(>10.0 \%)$, dominants $(5.01-10.0 \%)$, subdominants $(1.01-5.00 \%)$, recedents $(0.50-1.00 \%)$, subrecedents $(<0.50 \%)$ (Zawal et al., 2013). The occurrence of beetles during the period following the dredging was analyzed with respect to the following environmental factors: water flow velocity (flow; $\mathrm{m} \cdot \mathrm{s}^{-1}$ ), plant cover (plants; \%), dredging impact (dredging) and substrate composition (sand, silt, mud). Flow velocity was measured with a FlowTracker Acoustic Doppler Velocimeter. Vegetation cover was estimated visually by the phytosociological method developed by Braun-Blanquet (1964). Dredging impact was measured in terms of time from the investment (in months); it scored between 5 (samples collected directly after the dredging, in April 2009) and 1 (5 months after the dredging, in $\mathrm{Au}-$ gust 2009). Substrate composition was visually estimated as the proportions of fine and coarse sediment and organic matter. Similarities between stations (Bray-Curtis formula) were performed using Biodiversity Pro 2 software (McAleece et al., 1997). We used the DCA (Detrended Correspondence Analysis) multivariate ordination method (Hill and Gauch, 1980; ter Braak and Prentice, 1988) to assess the range of the environmental gradient. Having verified by DCA that the environmental gradient covered was sufficiently large, we used RDA (Redundancy Analysis) (ter Braak, 1986; ter Braak and Verdonschot, 1995) for community ordination of beetle assemblages in rela-

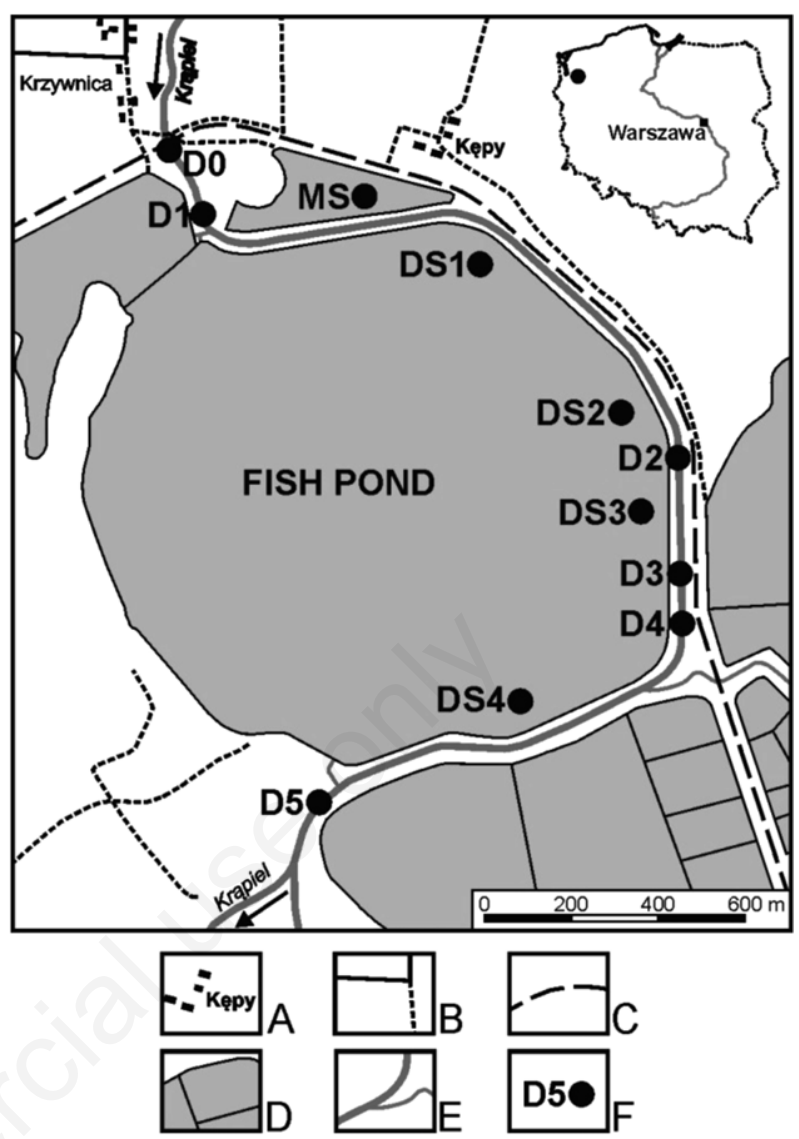

Fig. 1. Study area and sampling sites. A, buildings; B, roads; $\mathrm{C}$, rail road; D, fish ponds; E, running waters; F, sites.

Tab. 1. Characteristics of the sampled localities along the River Krapiel; control localities (undredged) were D0/1, D0/2, D4/1 and D4/2.

\begin{tabular}{|c|c|c|c|c|c|c|c|c|c|c|}
\hline \multirow[t]{3}{*}{ Sites } & \multicolumn{10}{|c|}{ Parameters } \\
\hline & \multicolumn{2}{|c|}{ Flow $\left(\mathrm{m} \cdot \mathrm{s}^{-1}\right)$} & \multicolumn{2}{|c|}{ Depth (m) } & \multicolumn{2}{|c|}{ Bottom } & \multicolumn{2}{|c|}{ Plants (\%) } & \multicolumn{2}{|c|}{ Shadow } \\
\hline & B & A & B & A & B & A & B & A & B & A \\
\hline D0/1 & 0.5 & $0.46-0.51$ & 0.7 & 0.7 & Gravel, stones & Gravel, stones & 0 & 0 & Lack & Lack \\
\hline $\mathrm{D} 0 / 2$ & 0.01 & $0.002-0.02$ & 0.5 & 0.5 & Sand, silt, mud & Sand, silt, mud & 70 & $50-70$ & Partly & Partly \\
\hline $\mathrm{D} 1 / 1$ & 0.013 & $0.09-0.16$ & 0.4 & 0.5 & Mud & Sand, gravel & 30 & $0-10$ & Lack & Lack \\
\hline $\mathrm{D} 1 / 2$ & 0.01 & $0.002-0.01$ & 0.2 & 0.2 & Silt, mud & Sand, silt, mud & 90 & $0-40$ & Partly & Lack \\
\hline $\mathrm{D} 2 / 1$ & 0.02 & $0.01-0.05$ & 0.2 & 0.5 & Silt, mud & Silt, mud & 90 & $0-10$ & Partly & Lack \\
\hline $\mathrm{D} 2 / 2$ & 0.002 & $0.001-0.002$ & 0.1 & 0.2 & Mud & Mud & 100 & $0-40$ & Partly & Lack \\
\hline $\mathrm{D} 3 / 1$ & 0.02 & $0.02-0.05$ & 0.3 & 0.5 & Silt, mud & Sand, silt, mud & 20 & $0-10$ & Partly & Lack \\
\hline $\mathrm{D} 3 / 2$ & 0.002 & $0.001-0.002$ & 0.1 & 0.2 & Mud & Sand, silt, mud & 80 & $0-40$ & Partly & Partly \\
\hline $\mathrm{D} 4 / 1$ & 0.14 & $0.09-0.2$ & 0.5 & 0.5 & Sand, gravel & Sand, gravel & 0 & 0 & Partly & Partly \\
\hline $\mathrm{D} 4 / 2$ & 0.003 & $0.001-0.003$ & 0.2 & 0.2 & Sand, mud & Sand, mud & 70 & $30-70$ & Partly & Partly \\
\hline $\mathrm{D} 5 / 1$ & 0.001 & $0.001-0.003$ & 0.5 & 0.7 & Mud & Mud & 40 & $0-40$ & Partly & Lack \\
\hline $\mathrm{D} 5 / 2$ & 0.04 & $0.03-0.06$ & 0.5 & 1.0 & Mud & Mud & 30 & $0-20$ & Lack & Lack \\
\hline
\end{tabular}

$B$, before dredging; $A$, after dredging. 
tion to environmental variables. Only the data from the river was used in both analyses. All species and variables were included into the analyses. The analyzed data was not transformed (O'Hara and Koetze, 2010). To assess the impact of dredging on the beetle community we used before-after-control-impact (BACI) analysis, which makes it possible to compare data obtained in the control stations with data obtained in the impacted stations before and after the intervention, i.e. in July 2008 and July 2009.

There are two aspects to be tested: BA, before and after; and CI, control and impact site. BACI is the test for the BA x CI interaction (Smith et al., 1993). The impact of dredging was tested in two ways: i) by testing Coleoptera abundance, expressed as the number of individuals at a given sampling station, with each species analyzed separately, and ii) by the Shannon-Wiener Index, with the Coleoptera biodiversity of each station analyzed separately. When the abundance of Coleoptera was used as the dependent variable, BACI was tested using a generalized mixed model (GLMM) with a log link and a negative binomial distribution (Tab. 2). This should be used when the dependent variable shows high variation. We considered species a random effect (intercept) with scaled identity covariance. In the second analysis, the ShannonWiener Index was treated as a dependent variable and BACI was tested by factorial ANOVA (Tab. 3).

\section{RESULTS}

Over the entire study period a total of 667 beetle individuals were collected, of which 638 were assigned to 63 species and 29 (mainly larvae) to 7 taxa of higher rank (Tab. 4). Prior to the dredging 96 individuals belonging to 27 species and two genera were collected in the river, and after the dredging 386 individuals belonging to 48 species, 4 genera and one family. In the five fish ponds separated from the river by a dike, 185 individuals belonging to 18 species and 4 genera were collected (Tab. 4). Four times as many individuals and nearly twice as many taxa were caught after the dredging because the material was collected over a longer period.

In all of the material analyzed, two species each were included among eudominants (Haliplus immaculatus,
$\mathrm{D}=17.7 \%$ and Hyphydrus ovatus, $\mathrm{D}=17.2 \%$ ) and dominants (Haliplus fluviatilis, $\mathrm{D}=9.3 \%$ and Laccobius minutus, $\mathrm{D}=5.1 \%$ ). There were also 9 subdominants and 57 recedents (Tab. 4). Haliplus fluviatilis and Haliplus immaculatus were found at the most sampling sites (nearly $69 \%$ and $62 \%$, respectively). Moreover, Hyphydrus ovatus, Hydraena riparia and Oulimnius tuberculatus were caught at least half of the sites. Only 14 species were found both before and after the dredging: Haliplus fluviatilis, H. ruficollis, H. flavicollis, Agabus bipustulatus, Ilybius ater, I. obscurus, Laccophilus hyalinus, L. minutus, Helophorus dorsalis, H. griseus, H. minutus, Hydrobius fuscipes, Hydraena riparia and Oulimnius tuberculatus. In addition to the qualitative composition of the assemblage, the dredging also had a significant effect on its quantitative structure. The pre-dredging eudominant Elmis aenea $(\mathrm{D}=24 \%)$ vanished completely, and the proportions of the other eudominants, Haliplus fluviatilis $(\mathrm{D}=18.8 \%)$ and Oulimnius tuberculatus $(\mathrm{D}=15.6 \%)$, decreased to $9.6 \%$ and $3.4 \%$, respectively. The contribution of Hydraena riparia decreased as well; before the dredging it was one of the dominants $(\mathrm{D}=7.3 \%)$, but afterwards was among the subdominants $(\mathrm{D}=4.7 \%)$ (Tab. 1$)$.

In the dominance structure after the dredging, the largest percentages in the assemblage were attained by the previously absent Hyphydrus ovatus $(\mathrm{D}=13.7 \%)$, Haliplus immaculatus $(\mathrm{D}=10.4 \%)$ and Laccobius minutus ( $\mathrm{D}=8.8 \%$ ). Besides L. minutus, the dominants also included Laccophilus minutus $(\mathrm{D}=5.7 \%)$ and L. hyalinus $(\mathrm{D}=5.4 \%)$, whose position rose after the dredging, and the previously mentioned $H$. fluviatilis, whose quantitative

Tab. 2. The tests of effects of the generalized mixed model model.

\begin{tabular}{lcccc} 
Source & $F$ statistics & df 1 & df 2 & Significance \\
Corrected model & 6.604 & 3 & 156 & 0.000 \\
Before-after & 2.238 & 1 & 156 & 0.137 \\
\hline Control-impact & 0.000 & 1 & 156 & 0.997 \\
BA x CI & 13.910 & 1 & 156 & 0.000 \\
\hline
\end{tabular}

$d f$, degree of freedom; BA, before and after; CI, control and impact site.

Tab. 3. The tests of effects of factorial ANOVA.

\begin{tabular}{lccccc} 
Source & Sum of squares & df & Mean square & F-statistic & P \\
Intercept & 50.253 & 1 & 50.253 & 101.452 & 0.000 \\
Before-after & 0.869 & 1 & 0.869 & 0.755 & 0.496 \\
Control-impact & 0.246 & 1 & 0.246 & 0.000 & 0.489 \\
BAx CI & 0.000 & 1 & 0.000 & 0.495 \\
\hline Error & 9.907 & 20 & & \\
\hline
\end{tabular}

$d f$, degree of freedom; BA, before and after; $C I$, control and impact site. 
Tab. 4. The quantitative statement of water beetles.

\begin{tabular}{|c|c|c|c|c|c|c|c|c|c|c|c|c|c|c|c|}
\hline \multirow[t]{2}{*}{ No. Species } & \multirow[t]{2}{*}{ Abb } & \multicolumn{5}{|c|}{$\begin{array}{c}\text { Total } \\
\text { material }\end{array}$} & \multicolumn{3}{|c|}{$\begin{array}{l}\text { River before } \\
\text { dredging }\end{array}$} & \multicolumn{3}{|c|}{$\begin{array}{l}\text { River after } \\
\text { dredging }\end{array}$} & \multicolumn{3}{|c|}{$\begin{array}{l}\text { Fish } \\
\text { ponds }\end{array}$} \\
\hline & & I & $\mathrm{L}$ & $\mathrm{I}+\mathrm{L}$ & D & F & n & D & F & n & D & F & n & D & F \\
\hline 1. Gyrinus natator (Linnaeus, 1758) & Gyr_nat & 1 & - & 1 & 0.1 & 6.3 & 1 & 1 & 10 & - & - & - & - & - & - \\
\hline 2. G. substriatus Stephens, 1829 & Gyr_sub & 3 & - & 3 & 0.4 & 12.5 & 3 & 3.1 & 20 & - & - & - & - & - & - \\
\hline 3. Haliplus flavicollis Sturm, 1834 & Hal_fla & 23 & - & 23 & 3.5 & 43.8 & 1 & 1 & 10 & 10 & 2.6 & 40 & 12 & 6.5 & 60 \\
\hline 4. H. fluviatilis Aubé, 1836 & Hal_flu & 62 & - & 62 & 9.6 & 68.8 & 18 & 18.8 & 30 & 36 & 9.4 & 60 & 8 & 4.3 & 60 \\
\hline 5. H. fulvus (Fabricius, 1801) & Hal_ful & 1 & - & 1 & 0.1 & 6.3 & - & - & - & - & - & - & 1 & 0.5 & 20 \\
\hline 6. H. heydeni Wehncke, 1875 & Hal_hey & 6 & - & 6 & 0.9 & 18.8 & - & - & - & 5 & 1.3 & 20 & 1 & 0.5 & 20 \\
\hline 7. H. immaculatus Gerhardt, 1877 & Hal_imm & 118 & - & 118 & 18.2 & 62.5 & - & - & - & 40 & 10.5 & 60 & 78 & 42.2 & 80 \\
\hline 8. H. ruficollis (De Geer, 1774) & Hal_ruf & 17 & - & 17 & 2.6 & 43.8 & 2 & 2.1 & 20 & 14 & 3.7 & 40 & 1 & 0.5 & 20 \\
\hline 9. Noterus clavicornis (De Geer, 1774) & Not_cla & 10 & - & 10 & 1.5 & 37.5 & - & - & - & 8 & 2.1 & 50 & 2 & 1.1 & 20 \\
\hline 10. N. crassicornis (O.F. Müller, 1776) & Not_cra & 13 & - & 13 & 2.0 & 25 & - & - & - & 10 & 2.6 & 30 & 3 & 1.6 & 20 \\
\hline 11. Agabus bipustulatus (Linnaeus, 1761) & Aga_bip & 2 & - & 2 & 0.3 & 6.3 & 1 & 1 & 10 & 1 & 0.3 & 10 & - & - & - \\
\hline 12. A. undulatus (Schrank, 1776) & Aga_und & 2 & - & 2 & 0.3 & 12.5 & - & - & - & 1 & 0.3 & 10 & 1 & 0.5 & 20 \\
\hline 13. Agabus sp. & Aga_spe & - & 15 & 15 & 2.3 & 43.8 & 1 & 1 & 10 & 12 & 3.1 & 50 & 2 & 1.1 & 40 \\
\hline 14. Ilybius ater (De Geer, 1774) & Ily_ate & 2 & - & 2 & 0.3 & 6.3 & 1 & 1 & 10 & 1 & 0.3 & 10 & - & - & - \\
\hline 15. I. fenestratus (Fabricius, 1781) & Ily_fen & 3 & 1 & 4 & 0.6 & 18.8 & - & - & - & 4 & 1.0 & 30 & - & - & - \\
\hline 16. I. fuliginosus (Fabricius, 1792) & Ily_ful & 15 & 1 & 16 & 2.5 & 18.8 & - & - & - & 16 & 4.2 & 30 & - & - & - \\
\hline 17. I. guttiger (Gyllenhal, 1808) & Ily_gut & 1 & - & 1 & 0.1 & 6.3 & - & - & - & 1 & 0.3 & 10 & - & - & - \\
\hline 18. I. quadriguttatus (Lacordaire, 1835) & Ily_qua & 3 & - & 3 & 0.4 & 6.3 & 1 & 1 & 10 & 2 & 0.5 & 10 & - & - & - \\
\hline 19. I. similis Thomson, 1856 & Ily_sim & 1 & - & 1 & 0.1 & 6.3 & - & - & - & - & - & - & 1 & 0.5 & 20 \\
\hline 20. I. subaeneus Erichson, 1837 & Ily_sub & 13 & - & 13 & 2.0 & 6.3 & - & - & - & 13 & 3.4 & 10 & - & - & - \\
\hline 21. Ilybius sp. & Ily_spe & - & 5 & 5 & 0.7 & 25 & - & - & - & 4 & 1.0 & 30 & 1 & 0.5 & 20 \\
\hline 22. Colymbetes fuscus (Linnaeus, 1758) & Col_fus & 1 & - & 1 & 0.1 & 6.3 & 1 & 1 & 10 & - & - & - & - & - & - \\
\hline 23. Colymbetes sp. & Col_spe & - & 2 & 2 & 0.3 & 6.3 & 2 & 2.1 & 10 & - & - & - & - & - & - \\
\hline 24. Rhantus exsoletus (Forster, 1771) & Rha_exs & 3 & - & 3 & 0.4 & 12.5 & - & - & - & 1 & 0.3 & 10 & 2 & 1.1 & 20 \\
\hline 25. R. suturalis (MacLeay, 1825) & Rha_sut & 1 & - & 1 & 0.1 & 6.3 & - & - & - & 1 & 0.3 & 10 & - & - & - \\
\hline 26. Acilius canaliculatus (Nicolai, 1822) & Aci_can & 1 & - & 1 & 0.1 & 6.3 & - & - & - & 1 & 0.3 & 10 & - & - & - \\
\hline 27. A. sulcatus (Linnaeus, 1758) & Aci_sul & 1 & - & 1 & 0.1 & 6.3 & - & - & - & 1 & 0.3 & 10 & - & - & - \\
\hline 28. Dytiscus dimidiatus Bergsträsser, 1778 & Dyt_dim & 1 & - & 1 & 0.1 & 6.3 & - & - & - & 1 & 0.3 & 10 & - & - & - \\
\hline 29. Dytiscus sp. & Dyt_spe & - & 1 & 1 & 0.1 & 6.3 & - & - & - & 1 & 0.3 & 10 & - & - & - \\
\hline 30. Hydaticus seminiger (De Geer, 1774) & Hyda_sem & 1 & - & 1 & 0.1 & 6.3 & 1 & 1 & 10 & - & - & - & - & - & - \\
\hline 31. Graptodytes pictus (Fabricius, 1787) & Gra_pic & 4 & - & 4 & 0.6 & 18.8 & - & - & - & 4 & 1.0 & 30 & - & - & - \\
\hline 32. Hydroporus angustatus Sturm, 1835 & Hyd_ang & 2 & - & 2 & 0.3 & 12.5 & - & - & - & 2 & 0.5 & 20 & - & - & - \\
\hline 33. H. palustris (Linnaeus, 1761) & Hyp_pal & 4 & - & 4 & 0.6 & 18.8 & - & - & - & 4 & 1.0 & 30 & - & - & - \\
\hline 34. H. planus (Fabricius, 1781) & Hyd_pla & 1 & - & 1 & 0.1 & 6.3 & 1 & 1 & 10 & - & - & - & - & - & - \\
\hline 35. H. rufifrons (Duftschmid, 1805) & Hyd_ruf & 1 & - & 1 & 0.1 & 6.3 & 1 & 1 & 10 & - & - & - & - & - & - \\
\hline 36. Suphrodytes dorsalis (Fabricius, 1787) & Sup_dor & 1 & - & 1 & 0.1 & 6.3 & 1 & 1 & 10 & - & - & - & - & - & - \\
\hline 37. Hygrotus impressopunctatus (Schaller, 1783) & Hyg_imp & 2 & - & 2 & 0.3 & 12.5 & - & - & - & 1 & 0.3 & 10 & 1 & 0.5 & 20 \\
\hline 38. H. inaequalis (Fabricius, 1777) & Hyg_ina & 6 & - & 6 & 0.9 & 25 & - & - & - & 5 & 1.3 & 30 & 1 & 0.5 & 20 \\
\hline 39. Hyphydrus ovatus (Linnaeus, 1761) & Hyp_ova & 56 & 59 & 115 & 17.7 & 56.3 & - & - & - & 53 & 13.9 & 50 & 62 & 33.5 & 80 \\
\hline 40. Laccophilus hyalinus (De Geer, 1774) & Lap_hya & 24 & - & 24 & 3.7 & 31.3 & 2 & 2.1 & 20 & 21 & 5.5 & 40 & 1 & 0.5 & 20 \\
\hline 41. L. minutus (Linnaeus, 1758) & Lap_min & 25 & - & 25 & 3.8 & 37.5 & 3 & 3.1 & 20 & 22 & 5.8 & 40 & - & - & - \\
\hline 42. Helophorus dorsalis (Marsham, 1802) & Hel_dor & 2 & - & 2 & 0.3 & 12.5 & 1 & 1 & 10 & 1 & 0.3 & 10 & - & - & - \\
\hline 43. H. griseus Herbst, 1793 & Hel_gri & 3 & - & 3 & 0.4 & 18.8 & 1 & 1 & 10 & 1 & 0.3 & 10 & 1 & 0.5 & 20 \\
\hline 44. H. minutus Fabricius, 1775 & Hel_min & 2 & - & 2 & 0.3 & 12.5 & 1 & 1 & 10 & 1 & 0.3 & 10 & - & - & - \\
\hline 45. H. nanus Sturm, 1836 & Hel_nan & 1 & - & 1 & 0.1 & 6.3 & - & - & - & - & - & - & 1 & 0.5 & 20 \\
\hline 46. Hydrochus crenatus (Fabricius, 1792) & Hyd_ere & 1 & - & 1 & 0.1 & 6.3 & - & - & - & 1 & 0.3 & 10 & - & - & - \\
\hline 47. Anacaena limbata (Fabricius, 1792) & Ana_lim & 6 & - & 6 & 0.9 & 18.8 & - & - & - & 6 & 1.6 & 30 & - & - & - \\
\hline 48. A. lutescens (Stephens, 1829) & Ana_lut & 2 & - & 2 & 0.3 & 6.3 & - & - & - & 2 & 0.5 & 10 & - & - & - \\
\hline 49. Cymbiodyta marginella (Fabricius, 1792) & Cym_mar & 1 & - & 1 & 0.1 & 6.3 & - & - & - & 1 & 0.3 & 10 & - & - & - \\
\hline 50. Enochrus melanocephalus (Olivier, 1772) & Eno_mel & 1 & - & 1 & 0.1 & 6.3 & - & - & - & 1 & 0.3 & 10 & - & - & - \\
\hline 51. E. testaceus (Fabricius, 1801 ) & Eno_tes & 2 & - & 2 & 0.3 & 12.5 & - & - & - & - & - & - & 2 & 1.1 & 40 \\
\hline
\end{tabular}


share in the assemblage decreased sharply. The subdominants, besides Oulimnius tuberculatus and Hydraena riparia (discussed in the preceding paragraph) were Ilybius fuliginosus $(\mathrm{D}=4.1 \%)$, Haliplus ruficollis $(\mathrm{D}=3.6 \%)$, Ilybius subaeneus $(\mathrm{D}=3.4 \%)$ and Haliplus flavicollis $(\mathrm{D}=2.6 \%)$. Among these, prior to the dredging no representatives of the genus Ilybius Erichson, 1832 were caught. The dominance structure of Coleoptera fauna in the ponds, although simplified in comparison with the river habitats, was characterized by a certain similarity to the assemblage of beetles inhabiting the river after the dredging. The eudominants were Haliplus immaculatus $(\mathrm{D}=42.2 \%)$ and Hyphydrus ovatus $(\mathrm{D}=33.5 \%)$, while Haliplus flavicollis was a dominant $(\mathrm{D}=6.5 \%)$ and Haliplus fluviatilis a subdominant ( $\mathrm{D}=4.3 \%)$ (Tab. 1).

Before the dredging the quantitative share of rheobionts (Hydraena riparia, H. gracilis, Elmis aenea, Limnius volckmari and Oulimnius tuberculatus) in the beetle assemblage in the river was $50 \%$, with a frequency reaching $40 \%$, but as many as $96 \%$ of individuals were caught at the two control sites $(79 \%$ at D0/1 and $17 \%$ at D4/1). Rheophiles (Haliplus fluviatilis, H. flavicollis and Laccophilus hyalinus) accounted for $21.9 \%$ of the assemblage, with a frequency reaching $50 \%$ (Tab. 1). In this case as well the vast majority of individuals $(80 \%)$ were caught at a control site (D0/2). Following the dredging the occurrence of only two rheobionts was noted $(O$. tuberculatus and $H$. riparia), and their percentage of the total number of individuals caught ( $8.3 \%$ ) decreased consider- ably as well, but their frequency at the sampling sites reached $90 \%$. Moreover, only $28 \%$ of the individuals belonging to these species were associated with the control sites. The quantitative share of rheophiles following the dredging increased slightly (22.7\%), but the increase in their number was pronounced (additionally noted were Ilybius fenestratus, I. fuliginosus and Laccobius striatulus), as was their frequency (about 70\%) (Tab. 4).

Since the size of the material caught in the river before and after the dredging and in the fish ponds was unequal, statistical analyses were performed in addition to simple comparison of the material. The differences obtained in abundance, species number and the Shannon-Weaver index, calculated for the river before and after the dredging, were statistically insignificant. The values for the Kruskal-Walliss test were $\mathrm{H}(1, \quad \mathrm{~N}=39)=1.800960$ $\mathrm{P}=0.1796 ; \mathrm{H}(1, \mathrm{~N}=39)=2.268030 \mathrm{P}=0.1321$; and $\mathrm{H}(1$, $\mathrm{N}=39)=3.328267 \mathrm{P}=0.0681$ ), respectively. The analysis of the material collected included a comparison of the beetle assemblages in the Krapiel before the dredging (in July 2008) and after it (in July 2009). The quantitative richness of the fauna was greater before the dredging (144 individuals, compared to 96 caught in the previous year), but this assemblage was characterized by somewhat lower species diversity (H' before the dredging: 2.5797; H' after the dredging: 2.5237). The statistical significance of the changes observed in beetle abundance was confirmed by a BACI test ( $\mathrm{F}: 13.910 ; \mathrm{P}=0.000$ ), while the decrease in biodiversity was statistically insignificant (Figs. 2 and 3).

Tab. 4. Continued from previous page.

\begin{tabular}{|c|c|c|c|c|c|c|c|c|c|c|c|c|c|c|c|}
\hline \multirow[t]{2}{*}{ No. Species } & \multirow[t]{2}{*}{ Abb } & \multicolumn{5}{|c|}{$\begin{array}{c}\text { Total } \\
\text { material }\end{array}$} & \multicolumn{3}{|c|}{$\begin{array}{l}\text { River before } \\
\text { dredging }\end{array}$} & \multicolumn{3}{|c|}{$\begin{array}{l}\text { River after } \\
\text { dredging }\end{array}$} & \multicolumn{3}{|c|}{$\begin{array}{l}\text { Fish } \\
\text { ponds }\end{array}$} \\
\hline & & I & $\mathrm{L}$ & $\mathrm{I}+\mathrm{L}$ & D & F & $\mathrm{n}$ & D & F & $\mathrm{n}$ & D & $\mathrm{F}$ & $\mathrm{n}$ & D & F \\
\hline 52. Enochrus sp. & Eno_spe & - & 1 & 1 & 0.1 & 6.3 & - & - & - & - & - & - & 1 & 0.5 & 20 \\
\hline 53. Helochares lividus (Forster, 1771) & Hel_liv & 1 & - & 1 & 0.1 & 6.3 & 1 & 1 & 10 & - & - & - & - & - & - \\
\hline 54. H. obscurus (O.F. Müller, 1776) & Hel_obs & 2 & - & 2 & 0.3 & 12.5 & - & - & - & - & - & - & 2 & 1.1 & 40 \\
\hline 55. Hydrobius fuscipes (Linnaeus, 1758) & Hyd_fus & 2 & - & 2 & 0.3 & 6.3 & 1 & 1 & 10 & 1 & 0.3 & 10 & - & - & - \\
\hline 56. Laccobius minutus (Linnaeus, 1758) & Lac_min & 34 & - & 34 & 5.2 & 31.3 & - & - & - & 34 & 8.9 & 50 & - & - & - \\
\hline 57. L. striatulus (Fabricius, 1801) & Lac_str & 1 & - & 1 & 0.1 & 6.3 & - & - & - & 1 & 0.3 & 10 & - & - & - \\
\hline 58. Cercyon bifenestratus Küster, 1851 & Cer_bif & 1 & - & 1 & 0.1 & 6.3 & 1 & 1 & 10 & - & - & - & - & - & - \\
\hline 59. Cercyon sp. & Cer_spe & 1 & - & 1 & 0.1 & 6.3 & - & - & - & 1 & - & 10 & - & - & - \\
\hline 60. Hydraena gracilis Germar, 1824 & Hyd_gra & 1 & - & 1 & 0.1 & 6.3 & 1 & 1 & 10 & - & - & - & - & - & - \\
\hline 61. H. palustris Erichson, 1837 & Hyd_pal & 1 & - & 1 & 0.1 & 6.3 & - & - & - & 1 & 0.3 & 10 & - & - & - \\
\hline 62. H. riparia Kugelann, 1794 & Hyd_rip & 25 & - & 25 & 3.8 & 56.3 & 7 & 7.3 & 30 & 18 & 4.7 & 80 & - & - & - \\
\hline 63. Ochthebius bicolon Germar, 1824 & Och_bic & 1 & - & 1 & 0.1 & 6.3 & - & - & - & 1 & 0.3 & 10 & - & - & - \\
\hline 64. O. dilatatus Stephens, 1829 & Och_dil & 1 & - & 1 & 0.1 & 6.3 & 1 & 1 & 10 & - & - & - & - & - & - \\
\hline 65. Elmis aenea (Ph. Müller, 1806) & Elm_aen & 23 & - & 23 & 3.5 & 6.3 & 23 & 24 & 10 & - & - & - & - & - & - \\
\hline 66. Limnius volckmari (Panzer, 1793) & Lim_vol & 2 & - & 2 & 0.3 & 6.3 & 2 & 2.1 & 10 & - & - & - & - & - & - \\
\hline 67. Oulimnius tuberculatus (Ph. Müller, 1806) & Oul_tub & 25 & 4 & 29 & 4.4 & 50 & 15 & 15.6 & 20 & 14 & 3.7 & 70 & - & - & - \\
\hline TOTAL & - & 573 & 89 & 662 & - & - & 96 & - & - & 381 & - & - & 185 & - & - \\
\hline
\end{tabular}

Abb, abbreviations used in the Figs. 7 and 8; L, larvae; I, imagines; $I+L$, total number of specimens; $D$, dominance; F, frequency; $n$, number of specimens. 
Substantial transformation of the species composition and dominance structure was noted as well: as many as 14 taxa present in July 2008 were not caught a year later, including the eudominant Elmis aenea and the subdominants Gyrinus substriatus, Colymbetes sp. and Limnius volckmari (Tab. 4). New species appeared and attained the status of eudominants (Hyphydrus ovatus, $\mathrm{D}=23.6 \%$ and Haliplus immaculatus, $\mathrm{D}=16.8 \%$ ) or dominant (Ilybius fuliginosus, $\mathrm{D}=7.6 \%$ ) (Fig. 4). Despite the fact that the percentage share of Haliplus fluviatilis in the community decreased from $18.8 \%$ to $12.5 \%$, this species maintained its role as a eudominant, and was also present at more sampling sites than before the dredging. Some species, such as Hydraena riparia and Oulimnius tuberculatus, remained in the community, but their abundance decreased considerably. This was particularly visible in the case of $O$. tuberculatus, one of the previous eudominants, whose abundance decreased fivefold. These two species formed the subdominant group in July 2009 together with another six taxa (Haliplus flavicollis, H. ruficollis, Laccobius minutus, Laccophilus minutus, Agabus sp. larvae and Chrysomelidae). The beetle assemblage formed after the dredging of the river underwent qualitative and quantitative changes. The number of species and their abundance increased systematically, attaining maximum values (31 taxa, 163 individuals) in August. The values for the Shannon-Weaver $(\mathrm{H})$ index changed as well, increasing systematically except for a slight decrease in June (Fig. 5). In the changes in the ecological structure of the beetle assemblage formed after the dredging it is noteworthy that in the first phase (April-May) it consisted almost exclusively of eurytopic species and those associated with small ponds. Then there was an increase in the proportion of rheophiles (Haliplus fluviatilis, Laccophilus

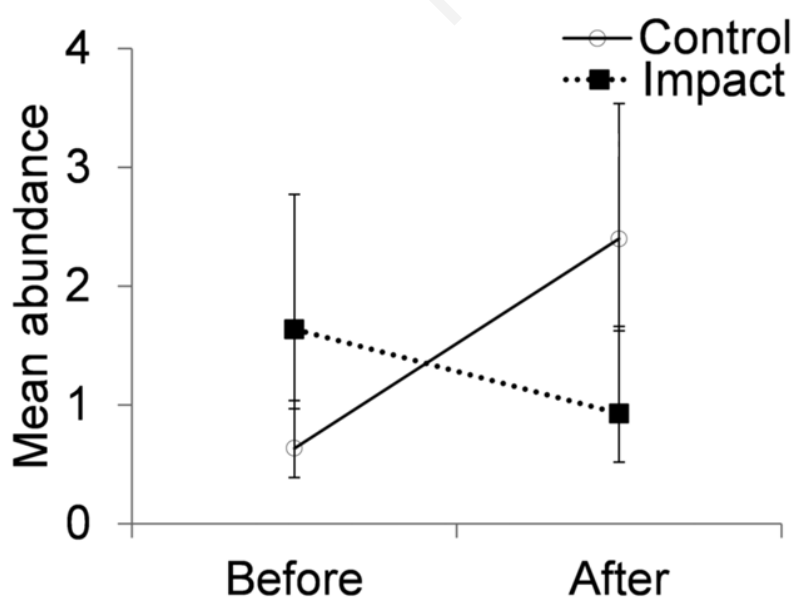

Fig. 2. Mean abundance of Coleoptera in BACI design (I - standard deviation). The interaction is significant at $\mathrm{P}=0.000$. hyalinus and Ilybius fuliginosus) and rheobionts (Hydraena riparia and Oulimnius tuberculatus), but the eurytopes maintained their dominant role (Fig. 4).

Before the dredging, the sampling sites in the Krapiel were characterized by relatively low faunal similarities. The most similar were the beetle assemblages at sites D5/1 and $\mathrm{D} 3 / 2(\mathrm{~S}=66.7 \%)$, with a very poor species composition and extremely low abundances of beetles, represented mainly by Laccophilus hyalinus. In this respect they also were, along with the Coleoptera fauna from site $\mathrm{D} 1 / 2$, the most distinct (Fig. 6). Essentially, before the dredging higher faunal similarity was noted at the sites associated with current environments than in marginal pools - the qualitative and quantitative compositions of the Coleoptera fauna at sites D1/1 and D3/1 were $33.1 \%$ similar, and together with the group of beetles from site D2/1 formed an association with similarity of $22.1 \%$. The assemblages from sites D01 and D4/1 were only $29.8 \%$ similar. The faunal similarities between the samples collected from different sites increased after the dredging, particularly within the marginal pool habitats, which often appeared in pairs on the dendrogram (Fig. 6). The most similar in terms of composition and abundance of Coleoptera fauna were samples $04 \mathrm{D} 1 / 2$ and $05 \mathrm{D} 3 / 2(100 \%)$, while the similarities between the marginal-pool samples forming the rest of the pairs ranged from $45.9 \%$ to $66.6 \%$. A high (70\%) degree of similarity was also observed in the fauna of samples 08D5/1 and 05D4/2, taken from different types of habitat, but such combinations were sporadic. Marked faunal similarity $(73.6 \%)$ was noted between samples 07D5/1 (river) and 07DS3 (pond DS3), which together with two other samples from the ponds formed a clearly separate subgroup with similarity between assemblages of about $64 \%$ (Fig. 6). Another group was formed by the fauna of the

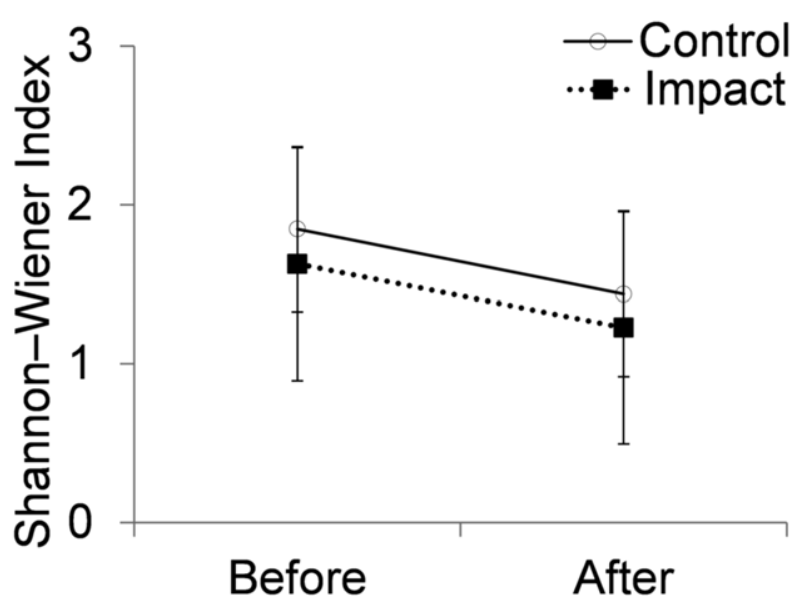

Fig. 3. Shannnon-Wiener Index of Coleoptera diversity (I - standard deviation). The interaction was not significant $(\mathrm{P}>0.05)$. 
fourth pond (DS4) together with assemblages of beetles collected from four of the marginal pool sites and one site in a current environment, but with similarity below $50 \%$. The two groups were part of a larger association combining a total of six samples from marginal pools, four from ponds and two from current environments, with $41.1 \%$ similarity. The similarity of another group of three samples from marginal pools and one from a site in a current environment was at a similar level (42.5\%) (Fig. 6). The DCA analysis for the beetle species before the dredging showed that the length of the gradient represented by the first ordination axis was 0.000 , which necessitated direct ordination analysis of the RDA type to determine the relationships between the occurrence of species and the environmental parameters tested in the Krąpiel (ter Braak, 1986; ter Braak and Verdonschot, 1995). The results of the direct RDA for the samples collected from the Krapiel before the dredging (Fig. 7) indicated that the variables used in the ordination explain $73.8 \%$ of the total beetle species variance. The results of the stepwise selection of environmental variables showed that of the five variables taken into account only one (flow) was statistically significant, explaining $9.91 \%$ of the range of total variance in occurrence of species $(\mathrm{P}=0.008)$. The ordination diagram illustrating the results of the RDA shows the occurrence of a group of species strongly correlated with water current, consisting mainly of rheophiles (Limnius volckmari, Elmis aenea, Hydraena riparia and $H$. gracilis) and the eurytopic species Hydaticus seminiger. Oulimnius tuberculatus (a rheobiont) mainly showed a tendency to be present at sandy sites with a pronounced current, and to a lesser degree on silt substrates, while avoiding habitats covered with mud or vegetation. The remaining beetle species present in the river before the dredging were weakly associated with this type of habitat (Fig. 7). The DCA analysis of the material collected after the dredging showed that the length of the gradient represented by the first ordination axis was 1.000, which necessitated direct ordination analysis of the RDA type. The results of the direct RDA for the samples collected from the Krapiel after the dredging indicated that the variables used in the ordination explain $19.0 \%$ of the total beetle species variance. The results of the stepwise

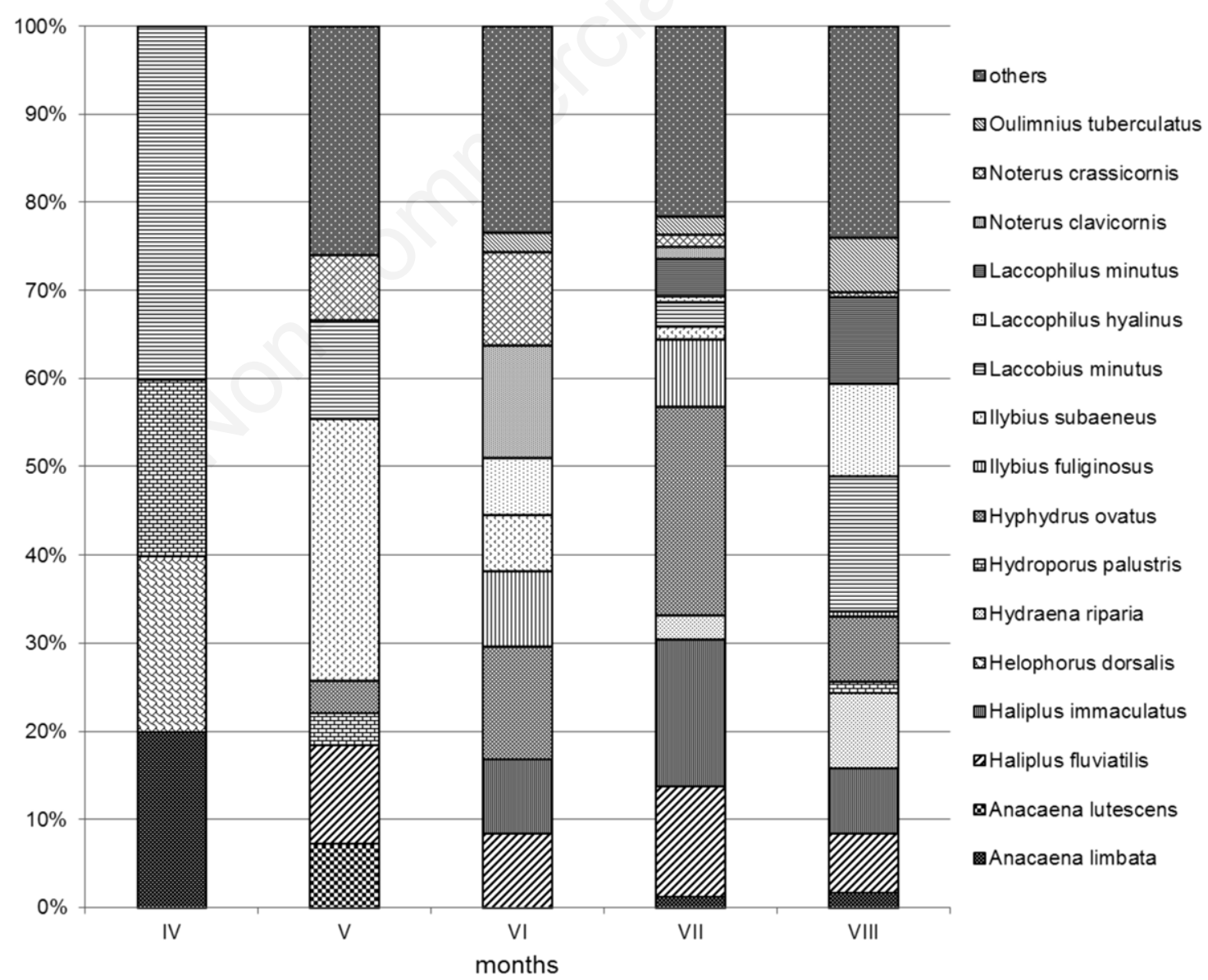

Fig. 4. Seasonal changes in the structure of domination of water beetles fauna in the river after dredging. 
selection of environmental variables showed that of the five variables taken into account only one (plants) was statistically significant for the total variance in occurrence of species $(\mathrm{P}=0.024)$. Most of the species in the RDA diagram have a wide range designated by vectors representing sediment type (silt and mud) and the degree of vegetation cover, and the most important environmental variables determining the beetle species variance were the amount of mud in the sediment, and above all, vegetation cover (Fig. 8). It can even be stated that the occurrence of most of the species was first determined by vegetation and then by the presence of a specific type of sediment, although the effect of the latter factor was not statistically significant. It is thus possible to distinguish a large group of species associated with the vegetation gradient and exhibiting a greater or lesser tendency to colonize environments with a silt substrate, including Oulimnius tuberculatus, Haliplus flavicollis, H. heydeni, H. fluviatilis, H. immaculatus, H. ruficollis, Laccobius striatulus, L. minutus, Laccophilus minutus, L. hyalinus, Agabus undulatus, Hyphydrus ovatus and Hydraena riparia. Another group preferred muddy substrates in varying degrees, while clearly avoiding heavily dredged habitats, e.g. Ilybius fuliginosus, Anacaena limbata, Coelambus impressopunctatus, Hygrotus inaequalis and Noterus crassicornis (Fig. 8). A tendency to occur in muddy but not necessarily overgrown habitats was exhibited by another group of species: Ilybius subaeneus, I. obscurus, Anacaena lutescens, Hydrobius fuscipes, Enochrus melanocephalus, Hydroporus angustatus, Rhantus exsoletus and Agabus bipustulatus. The gradients of water current, drainage and sand and silt substrate were associated with single species, with water current having the weakest influence on the species variance. A clear tendency to inhabit dredged habitats was exhibited by two species: Ilybius guttiger and $H y$ droporus palustris (Fig. 8).

\section{DISCUSSION}

Successional processes in the river, manifested as accumulation of organic sediment, development of vegetation and decreased water flow velocity in the river channel, lead to a reduction in the quantity and quality of current environments associated with lotic water bodies, preferred by a number of rheobiontic species of beetles (Elliott, 2008; Sarr et al., 2013). Accumulation of mud and overgrowth in marginal pools, especially by helophytes, decrease the heterogeneity of these habitats, affecting the assemblages inhabiting them. Such effects of progressive succession can be seen in the state of the Coleoptera fauna of the Krapiel prior to the dredging. Rheobionts and rheophiles (e.g., Haliplus fluviatilis, $\mathrm{Hy}$ draena riparia, Elmis aenea and Oulimnius tuberculatus) were represented in large numbers mainly at the control sites (especially D01 and D02). These were species typi- cal of the middle part of the rhithral zone, particularly Elmidae (Klausnitzer, 1996). The control sites had the best preserved natural microhabitat structure (riffles and marginal pools), by far the greatest species diversity, and above all, the greatest richness of beetles in the entire investigated stretch of the Krapiel. For this reason, most of the material from the period before the dredging was collected at these sites, which was why the dominance structure of the beetles during this period was atypical of a river of this size (Wichtowska and Sobczak, 1994; Pakulnicka and Nowakowski, 2012). The remaining sites, with less habitat heterogeneity, especially in terms of flow and sediment type, had beetle assemblages that were quantitatively and qualitatively poorer. A similar relationship between richness of Coleoptera fauna and habitat heterogeneity in an alluvial river floodplain was observed by Richoux (1994), who found that richness increased with the spatial and temporal diversity of habitats, attaining its maximum value where their diversity was moderate. One manifestation of the lack of ecological separateness of the riffles and marginal pools in the stretch of the Krapiel studied was the dominance of eurytopic species in current environments. The sites randomly colonized by Coleoptera fauna with a large proportion of eurytopic species had surprisingly low faunal similarity. A similar increase in the proportion of eurytopic species in river valley habitats accompanied by a decrease in their integrity due to unfavorable changes in hydrographic conditions was observed by Biesiadka and Pakulnicka (2004) in the valley of the River Narew, although they were least visible in the river channel itself. At the same time, species typical of small water bodies, which made up a substantial proportion of the Coleoptera fauna of the Narew, were its most dispersive and variable element (Biesiadka and Pakulnicka, 2004). The current environments in the River

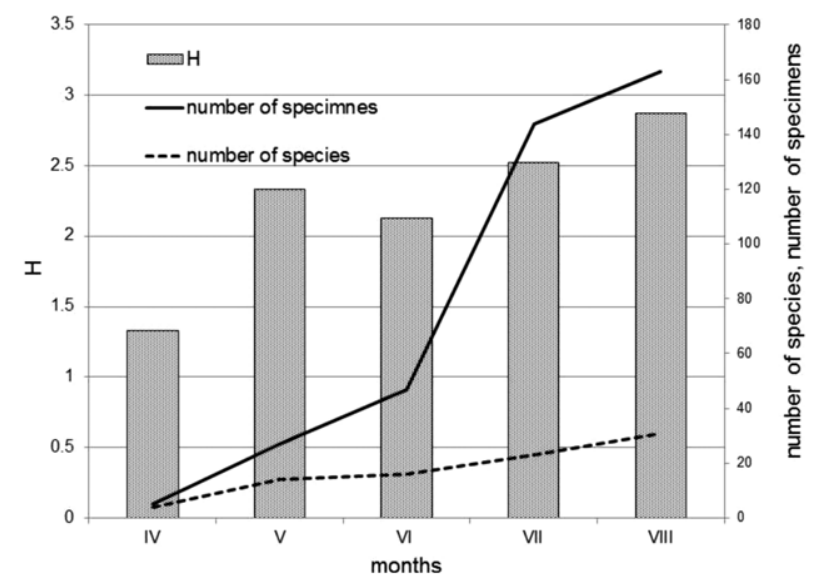

Fig. 5. Number of species, number of specimens and ShannonWiener Index $(\mathrm{H})$ in particular months after dredging. 
Krapiel, colonized to a greater extent than the marginal pools by more specialized and less mobile species, had a higher degree of faunal integration than the marginal pools. The main determinant of the similarity between these habitats and the beetle communities inhabiting them before the dredging was water current, and to a lesser extent substrate type, which was reflected in the statistically significant effect of water flow velocity on the species variance observed in the river.

Dredging of the investigated stretch of the river can be regarded as a forced and sudden process of ecological retrogression restoring the previous structure of open current environments with a mineral/organic substrate and marginal pools partially overgrown with vegetation and having a
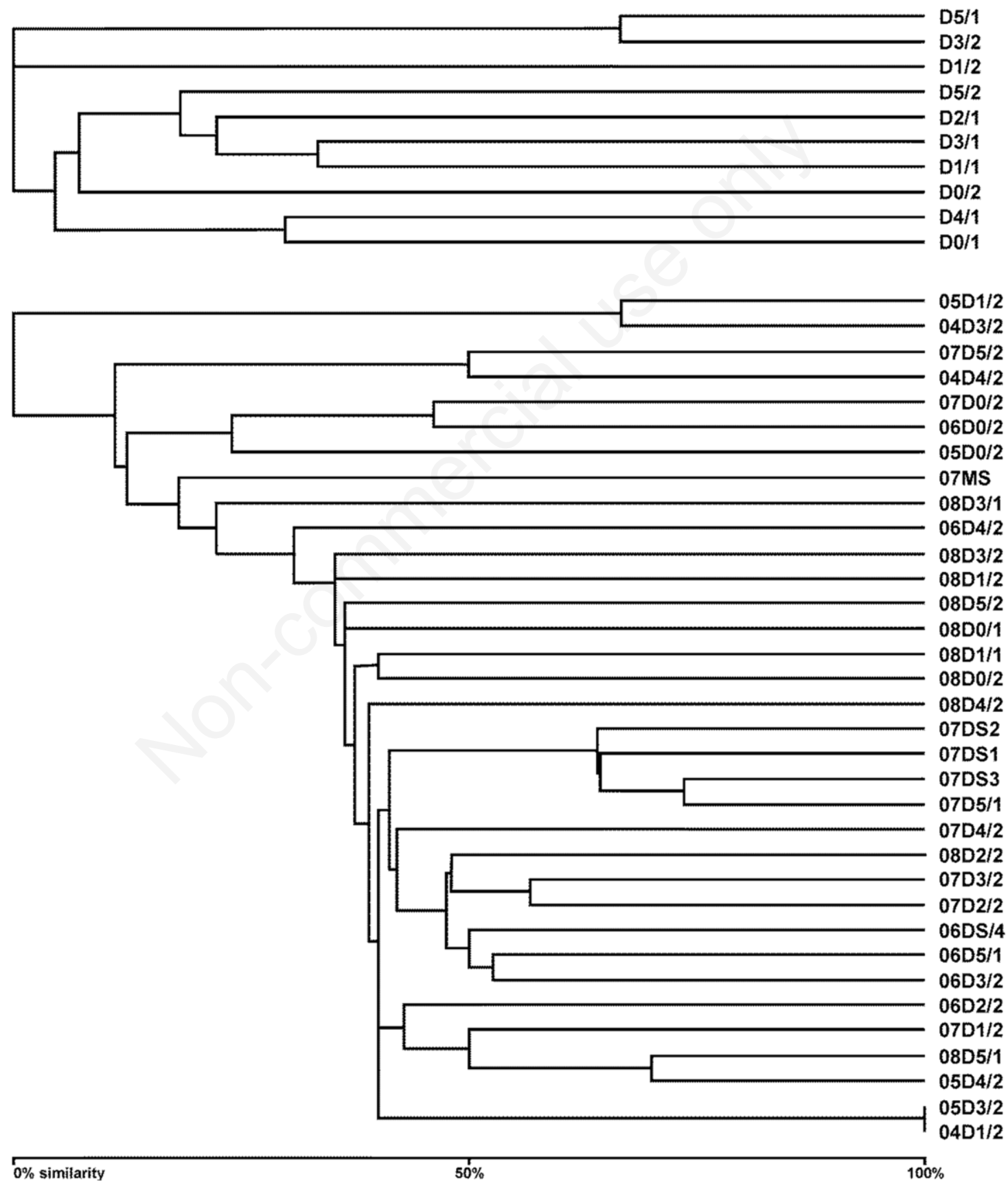

Fig. 6. Dendrogram of faunistic similarities between stations before dredging (above), and after dredging (below). The first two digits indicate the month of sampling, the last one the nature of the habitat (1, current; 2, lentic). D, stations in the river; S, stations in the fish ponds. 
greater proportion of organic sediment. In this respect it is a procedure increasing, on balance, habitat heterogeneity in the river channel (Tab. 1). A review paper by Niemi et al. (1990) on the impact of various types of anthropogenic disturbances on water systems indicates that dredging is one of the less devastating for aquatic biocoenoses. According to incomplete literature data, restoration of the prior invertebrate biomass takes place within 13 months, while species density and richness are usually restored within a week or two, less often requiring a few months or a year. Relatively rapid restoration of benthonic macrofauna following dredging has also been noted by van Dolah et al. (1984), McCabe et al. (1998), Szlauer-Łukaszewska and Zawal (2014) and Zawal et al. (2015, 2016a, 2016b). The efficiency of recolonization processes depends on a number of ecological fac- tors (intensity and duration of the disturbance, including changes in the integrity of the system and its productivity, the time of year it takes place, the distance and location of centers of recolonization, or the presence of refuges), and on the biology and phenology of particular groups of invertebrates (life cycles, duration of a generation, frequency and length of periods of appearance, or dispersal capacities), while recolonization processes can be completed within a week to over a year after the cause of the disturbance ceases (Niemi et al., 1990; Yount and Niemi 1990; Wilber and Clark, 2007). The speed of restoration of the original habitat conditions (e.g., sediment structure) and the degree of interference in the environment are significant elements determining the efficiency of recolonization. Removal of material from the river bottom has a complex impact on the

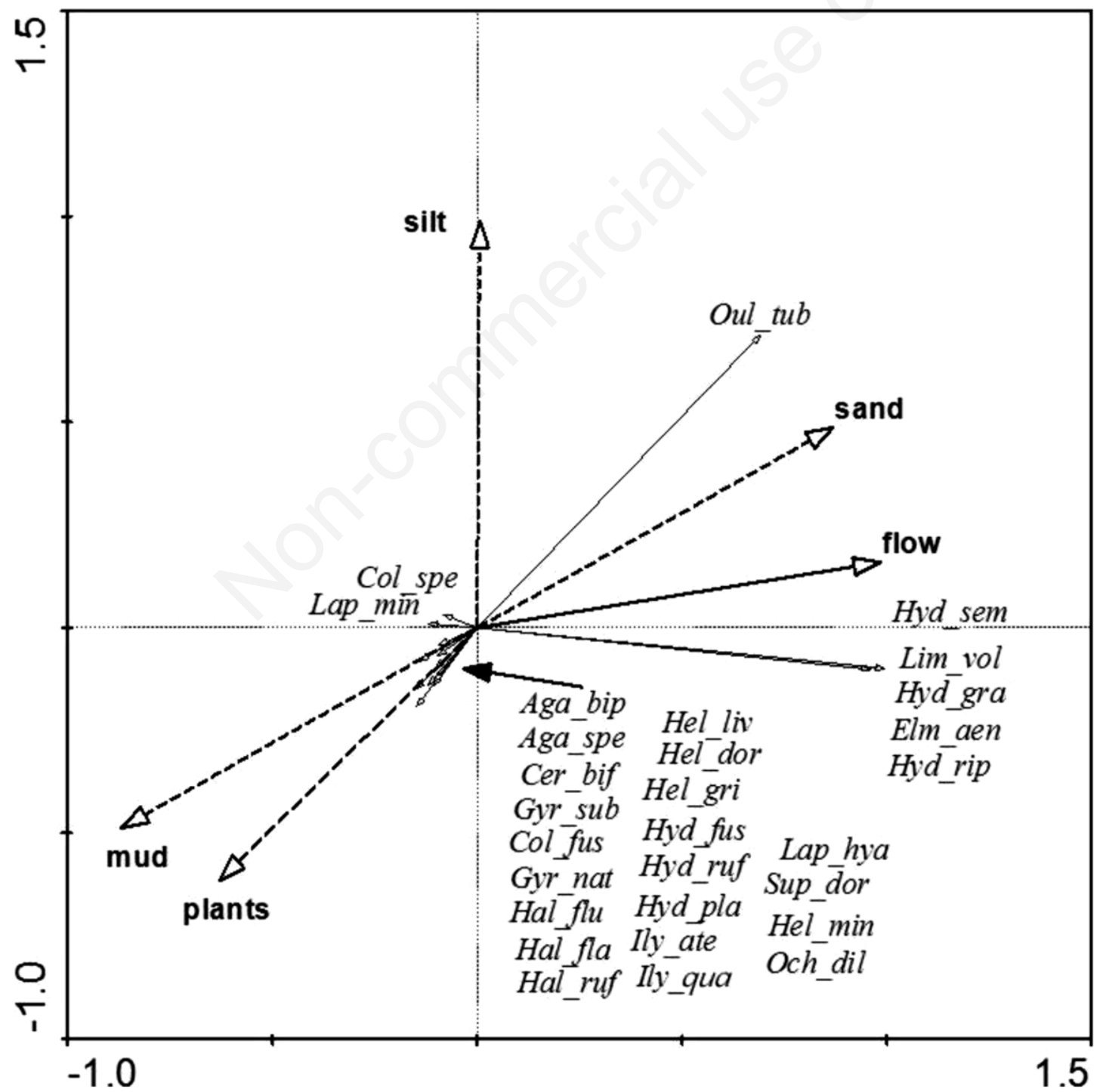

Fig. 7. RDA analysis of water beetles species before dredging. 
biocoenosis, as on the one hand fine-grained sediment reduces penetration of the bottom by water, affecting the circulation of biogenic compounds and gases, so its removal can be beneficial, while on the other hand the presence of particular types of sediment and their transport influences the structure of benthic fauna, including beetles (Eyre et al., 1993; Cortes et al., 2002; Svendsen et al., 2007). Removal of littoral vegetation, though it may directly contribute to a

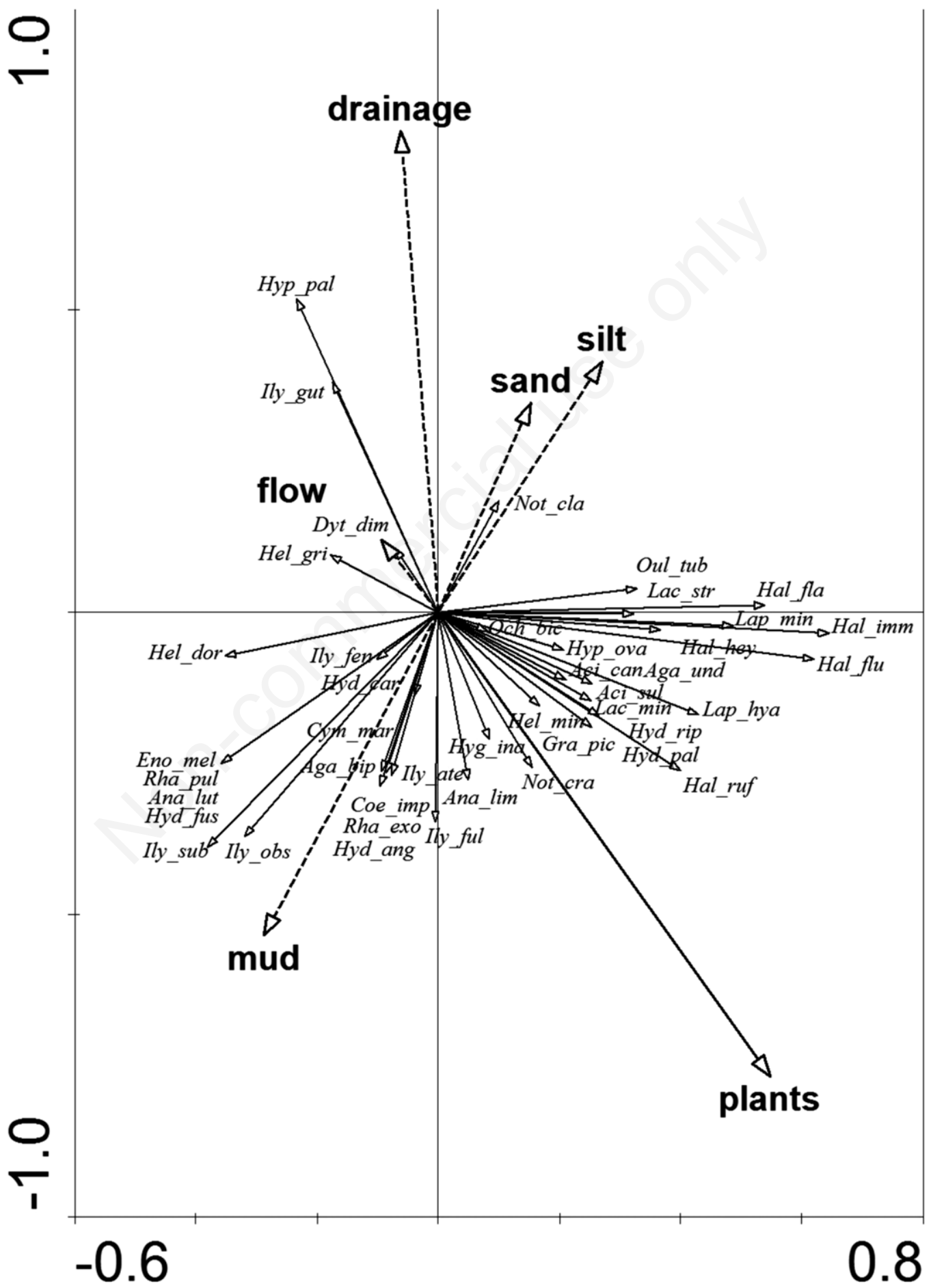

Fig. 8. RDA analysis of water beetles species after dredging. 
reduction in the density of fauna, ultimately leads to improved light conditions and higher water temperature in the watercourse, thereby stimulating an increase in invertebrate biomass. On the other hand, elimination of obstructions decreases habitat diversity in the river (Hawkins et al., 1982; Allan, 1995; Aldridge, 2000).

The dredging work carried out in the Krapiel clearly influenced the qualitative and quantitative structure of the beetle fauna inhabiting it, although the assessment of the impact of the disturbance is not unequivocal. The dredging caused profound changes in beetle assemblages, manifested as the withdrawal of nearly half of the previously occurring species and the formation of a new dominance structure, clearly distinct from the structure prior to the dredging. The recolonization processes were dynamic, offsetting within half a year the momentary impoverishment of fauna and reduction in species diversity indices, which confirms earlier information that dredging has a short-term impact on the benthos at the species level and it is quickly restored (Pearson and Jones, 1975; Yount and Niemi, 1990), although the total abundances of the zoobenthos in the undredged stretches of the river may be lower (Haynes and Makarewicz, 1982). In the Krąpiel, however, the habitat changes caused by the dredging resulted in increases in both abundance and species richness of Coleoptera fauna. Although in the scale of the entire period studied these were not statistically significant changes, comparison of fauna from analogous periods before and after the dredging reveals marked differences between the two assemblages. In the long term, the differences between the macrozoobenthos of the dredged and undredged stretches of the river are obliterated (Skilleter, 2002).

Recolonization of the Krapiel was more efficient in the case of eurytopic species, mainly associated with marginal pools, which were the first to be colonized. Beetle populations in nearby standing water bodies, constituting focal points for insect dispersal, may have played a significant role in this process. The qualitative and quantitative structure of beetle assemblages at many of the river sites associated mainly with marginal pools was indicative of the effect of the Coleoptera fauna of fish ponds, which was reflected in the overall faunal similarity between the entire fauna of the analyzed stretch of the river after the dredging and the beetle fauna in these ponds. Fish ponds can be regarded here as an ecological equivalent of oxbow lakes, small water bodies, or even flow-through lakes, which have a significant role in integration of fauna within river systems (Czachorowski et al., 1993; Williams et al., 2003; Biesiadka and Pakulnicka, 2004; Pakulnicka and Nowakowski, 2012). We also know that they can be local centers of species diversity of aquatic insects (Buczyńska et al., 2007; Buczyński, 2015). Colonization by species from outside the river channel of slower niches appearing as a result of dredging may have contributed to the increased faunal similarity of the Coleoptera fauna of the marginal pools in 2009. The ability of many aquatic beetle species to fly even long distances has been demonstrated in experiments (Davy-Bowker, 2002). On the other hand, this may also have been the consequence of dispersal of beetles along the river as an ecological corridor, particularly as a result of drift of insect larvae and adult individuals from its course upstream from the study area (Benke et al., 1991; Rincón and Lobón-Cerviá, 1997; Brittain and Eikeland, 1988). This would be consistent with the autoregressive model of the effect of adjacent sites on the species composition of macrofauna in the catchment of the River Rede, which suggests that this effect is dependent on the migratory capacity of fauna and on habitat parameters, such as stream structure (type of sediment and degree of vegetation cover), and in the case Coleoptera, $\mathrm{pH}$ and water depth (Sanderson et al., 2005). Beetles could inhabit all suitable habitats, irrespective of distance. Hence in contrast to other, less mobile groups of insects, they did not form a group of species specific for neighboring sites (Sanderson et al., 2005). While this model did not take into account significant differences in the possibility of migration for particular synecological groups of beetles in the river, the differences we found in the rate of colonization of habitats in the dredged stretch of the Krapiel by rheobionts and stagnobionts with varied dispersal capacity is clearly in line with this conception.

Recolonization of the Krapiel by mobile beetle species probably took place in the two ways described above, i.e., by migration along the river and from outside of it, which is reflected in the spatial and temporal differentiation of beetle assemblages at individual sampling sites. In the case of some taxa, such as Hyphydrus ovatus or Agabus spp., success in colonizing certain sites was linked to the ability to reproduce efficiently in new habitats. The rate of recolonization was clearly linked to the typical seasonal dynamics of abundance in beetle populations, speeding up in the summer, when new generations of adults appear and intensive migration from small, astatic pools takes place. Seasonality is also one of the main factors determining the variation in local habitat conditions, thereby influencing the nature of the Coleoptera fauna which is present (Pakulnicka and Nowakowski, 2012).

Restoration was observed to be markedly slower in the case of populations typical of flowing water bodies, i.e., rheophiles and in particular rheobionts, which are characterized by more frequent utilization of drift as a significant mechanism of dispersal, and above all by considerably lower dispersal capacity (Brusven, 1970; Arribas et al., 2012; Sertić Perić et al., 2014). Another reason may be their relatively low representation in many slowflowing lowland watercourses of northern Poland, which especially refers to Elmidae and, to some extent, Hydraenidae Deronectes spp. (Biesiadka and Pakulnicka 
2004; Buczyński and Przewoźny 2009a, 2009b). The occurrence in lower numbers and at smaller numbers of sites limits the rate of recolonization by its nature.

First (May-June), more mobile rheophilic species with broader ecological valence appeared (e.g., Haliplus fluviatilis, Laccophilus hyalinus and Ilybius fuliginosus), only later (June-July) to be followed by rheobionts with lower migratory capability (Oulimnius tuberculatus and $\mathrm{Hy}$ draena riparia), and their abundance did not significantly increase until August. Recolonization was manifested not only as an increase in the quantitative share of typical river species in the beetle assemblages, but also in their occupation of an increasing number of sampling sites. A significant feature of the dispersal of $O$. tuberculatus and $H$. riparia was their exploitation of habitats with clearly altered ecological characteristics resulting from the dredging. Perhaps the environmental conditions that were changed at the dredged sites (such as increased water flow or the absence of muddy sediment) were within their ecological minima. This is also an indication of a pronounced tendency to migrate, which suggests that following stabilization of environmental parameters disturbed by dredging, these species will take over more habitats.

It is worth mentioning that after the dredging we observed species whose habitat requirements are less strict among the rheobionts. For example, Oulimnius tuberculatus does not exhibit strong preferences in terms of mineral substrate and is encountered in habitats covered with macrophytes (Elliott, 2008; Sarr et al., 2013). This tendency can also be seen in our data. In contrast, after the dredging - at least in the first year, taken into account in our study the most demanding and ecologically conservative species did not appear, such as Elmis aenea and Limnius volckmari, which have specific requirements in terms of substrate type, vegetation and water current (Eyre et al., 1993; Elliott, 2008). The increased water flow and partial removal of muddy sediment were insufficient for these species to appear. Due to the environmental conditions in the analyzed stretch of the Krapiel River, their occurrence was mainly limited to places represented by control site D0/1. It is worth emphasizing that such habitats, sometimes anthropogenic (e.g., artificial rapids), are extremely important for local biological diversity. River fragments that are varied in terms of habitats, with a well-developed pool-riffle sequence and marginal pools, constitute refuges and potential centres of dispersal for rheobiontic fauna with lower migration capacity. Therefore it is worth leaving them untouched during hydrotechnical work.

The dramatic changes observed in the qualitative and quantitative structure of beetle assemblages at the control sites suggest that they were characterized by biocoenoses with little stability. This may have been influenced by their relatively small share of the total area and number of habitats in the lower course of the Krąpiel, as well as the relatively high degree of isolation. Although we do not know the direct causes of the disappearance of Limnius volckmari from site D0/1, and especially that of the previously abundant Elmis aenea, due to the location of the site it could not have been the result of the dredging. Both of these species are sensitive to reductions in oxygen and low water flow, but these factors were not severely disturbed. The disappearance of $E$. aenea may have been linked to changes in the quality of the substrate, which consisted of mosses preferred by this species (Elliott, 2008; Sarr et al., 2013).

\section{CONCLUSIONS}

Vegetation cover and the type of bottom sediment are considered to be among the most significant environmental factors influencing beetle species variation in river ecosystems (Eyre et al., 1993, 2005; Sanderson et al., 2005; Pakulnicka and Nowakowski, 2012; Sarr et al., 2013). Although most of the studies cited above deal with the fauna and environment of streams, which are not an accurate reflection of the river ecosystem represented by the Krąpiel, a clear analogy can be perceived in the mechanisms regulating the biocoenotic relationships in these two types of water body. The presence of fine sediment (silt) in the form of clay or peat was the most significant environmental variable in one such network of streams, determining the occurrence of a number of Agabus spp., Anacaena spp., Hydroporus spp., Helophorus spp. and Hydrobius spp. (Eyre et al., 1993). They were also part of a larger group of beetle species (including Ilybius fuliginosus) that preferred habitats with well-developed littoral vegetation. Rheobionts, on the other hand (e.g., Elmis aenea, Oulimnius tuberculatus, Hydraena gracilis and Limnius volckmari) preferred habitats with a gravel and rocky substrate with a small amount of vegetation, both littoral and in the channel of the watercourse. This makes it possible to distinguish two main communities inhabiting watercourses. One of these prefers habitats with rich vegetation and a soft substrate, while the other is associated with the presence of exposed sediment with greater grain size and a small amount of vegetation (Eyre et al., 1993). The occurrence of particular beetle species in the stretch of the Krapiel that we investigated was consistent with this classification. This pattern was markedly more visible after the dredging. The removal of some of the vegetation led to an increase in habitat variation and probably caused Coleoptera fauna to cluster in habitats with more of this environmental component. According to Richoux's paradigm (1994), an increase in habitat heterogeneity led to an increase in the richness of Coleoptera fauna.

The diversity of beetle communities is also affected by water depth and flow velocity (Pakulnicka and Nowakowski, 2012; Williams et al., 2003). The second of these parameters, although it can be subject to significant 
changes in a dredged river, was one of the less important environmental factors for beetle species variation in the Krapiel. The changes in water flow after the dredging in this particular case were probably too subtle to result in the striking habitat variation that was observed at the control sites. In general, worth mentioning is the difference in total variance of the beetles explained by the environmental variables before and after dredging. In the second case its relatively small value may indicate that others than five examined factors play more important role in shaping the beetle communities after man-made disturbances, e.g., physico-chemical, hydromorphological or even those connected with watershed. Without doubts, this problem should be studied comprehensively in the future.

\section{ACKNOWLEDGMENTS}

Financial support was provided by the Ministry of Science and Higher Education, no. N305 222537. We are also grateful to the anonymous Reviewers for all valuable suggestions that have improved the manuscript.

\section{REFERENCES}

Aldridge DC, 2000. The impacts of dredging and weed cutting on a population of freshwater mussels (Bivalvia: Unionidae). Biol. Cons. 95:247-257.

Allan JD, 1995. Stream ecology: structure and function of running waters. Chapman and Hall, London.

Arribas P, Velasco J, Abellán P, Sánchez-Fernández D, Andújar C, Calosi P, Millán A, Ribera I, Bilton DT, 2012. Dispersal ability rather than ecological tolerance drives differences in range size between lentic and lotic water beetles (Coleoptera: Hydrophilidae). J. Biogeogr. 39:984-994.

Benke AC, Parsons KA, Dhar SM, 1991. Population and community patterns of invertebrate drift in an unregulated coastal plain river. Can. J. Fish. Aquat. Sci. 56:2041-2050.

Biesiadka E, Pakulnicka J, 2004. Water beetles (Coleoptera) in Łomżyński Landscape Park of Valley of Narew River. Parki Nar. Rez. Przyr. 23:427-447.

Braun-Blanquet J, 1964. Pflanzensoziologie. Grundzüge der Vegetationskunde. Spriger, Vienna.

Brittain JE, Eikeland JT, 1988. Invertebrate drift - A review. Hydrobiologia 166:77-93.

Brusven MA, 1970. Drift periodicity of some riffle beetles (Coleoptera: Elmidae). J. Kans. Ent. Soc. 43:364-371.

Buczyńska E, Buczyński P, Lechowski L, Stryjecki R, 2007. Fish pond complexes as refugia of aquatic invertebrates (Odonata, Coleoptera, Heteroptera, Trichoptera, Hydrachnidia): A case study of the pond complex in Zalesie Kańskie (Central-East Poland). Nat. Conserv. 64:39-55.

Buczyński P, 2015. Dragonflies (Odonata) of anthropogenic waters in middle-eastern Poland. Mantis, Olsztyn.

Buczyński P, Przewoźny M, 2009a. Aquatic beetles (Coleoptera) of Wdzydze Landscape Park (Tuchola Forests, N Poland). Nat. J. 42:67-85.

Buczyński P, Przewoźny M, 2009b. Materiały do poznania chrząszczy wodnych (Coleoptera) Polski północnej. Wiad. Entomol. 28:43-52.
Cavailléa P, Dommangeta F, Daumerguea N, Loucougaraya G, Spiegelbergera T, Tabacchib E, Evettea A, 2013. Biodiversity assessment following a naturality gradient of riverbank protection structures in French prealps rivers. Ecol. Eng. 53:23-30.

Cortes RMV, Ferreira MT, Oliveira SV, Oliveira D, 2002. Macroinvertebrate community structure in regulated river segment with different flow conditions. River Res. Applic. 18:367-382.

Czachorowski S, Lewandowski K, Wasilewska A, 1993. The importance of aquatic insects for landscape integration in the catchment area of the river Gizela (Masurian Lake District, northeastern Poland). Acta Hydrobiol. 35:49-63.

Davy-Bowker J, 2002. A mark recapture study of water beetles (Coleoptera: Dytiscidae) in a group of semi-permanent and temporary ponds. Aquat. Ecol. 36:435-444.

de Jonge VN, de Jong DJ, 2002. Ecological restoration in coastal areas in the Netherlands: concepts, dilemmas and some examples. Hydrobiologia 478:7-28.

Elliott MJ, 2008. The ecology of riffle beetles (Elmidae). Freshw. Rev. 1:189-203.

Eyre MD, Pilkington JG, Carr R, McBlane RP, Rushton SP, Foster GN, 1993. The running-water beetles (Coleoptera) of a river catchment in northern England. Hydrobiologia 264:33-45.

Eyre MD, Pilkington JG, McBlane RP, Rushton SP, 2005. Macroinvertebrate species and assemblages in the headwater streams of the River Tyne, northern England in relation to land cover and other environmental variables. Hydrobiologia 544:229-240.

Hawkins CP, Murphy ML, Anderson NH, 1982. Effects of canopy, substrate composition, and gradient on the structure of macroinvertebrate communities in Cascade Range streams of Oregon. Ecology 63:1840-1856.

Haynes JM, Makarewicz JC, 1982. Comparison of benthic communities in dredged and undredged areas of the St. Lawrence River, Cape Vincent, N.Y. Ohio J. Sci. 82:165-170.

Hill MO, Gauch HG, 1980. Detrended correspondence analysis: An improved ordination technique. Vegetatio 42:47-58.

Klausnitzer B, 1996. [Käfer im und am Wasser].[Book in German]. Westarp Wissenschaften, Magdeburg: 200 pp.

Kordylas A, 1990. Water beetles in the Pasłęka River, north-east Poland. Latissimus 46:16-21.

Kowalik W, Buczyński P, 2003. Beetles (Coleoptera) of saline waters from "Bogdanka" stone coal mine (South-Eastern Poland). Acta Agroph. 1:115-121.

Lewis MA, Weber DE, Stanley RS, Moore JC, 2001. Dredging impact on an urbanized Florida bayou: effects on benthos and algal-periphyton. Environ. Pollut. 115:161-171.

McAleece N, Lambshead PJD, Paterson GLJ, 1997. BioDiversity Professional statistics analysis software. Jointly developed by the Scottish Association for Marine Science and the Natural History Museum London.

McCabe GT Jr, Hinton SA, Emmelt RL, 1998. Benthic invertebrates and sediment characteristics in a shallow navigation channel of the Lower Columbia River, before and after dredging. Northwest Sci. 72:116-126.

Miserendino ML, Archangelsky M, 2006. Aquatic Coleoptera distribution and environmental relationships in a large Patagonian river. Int. Rev. Hydrobiol. 91:423-437.

Niemi G, deVore P, Detenbeck N, Taylor D, Lima A, Pastor J, 
Yount JD, Naiman JR, 1990. Overview of case studies on recovery of aquatic systems from disturbance. Environ. Manage. 14:571-587.

O'Hara RB, Kotze DJ, 2010. Do not log-transform count data. Meth. Ecol. Evol. 1:8-122.

Ohimain EI, Imoobe TOT, Benka-Coker MO, 2005. The impact of dredging on macrobenthic invertebrates in a tributary of the Warri River, Niger delta. Afr. J. Aquat. Sci. 30:49-53.

Pakulnicka J, Nowakowski JJ, 2012. The effect of hydrological connectivity on water beetles fauna in water bodies within the floodplain of a lowland river (Neman river, Belarus). Oceanol. Hydrobiol. St. 41:7-17.

Pakulnicka J, Zawal A, 2012. [Chrząszcze wodne (Coleoptera) rezerwatu "Źródlisko Skrzypowe"].[Article in Polish]. Parki Nar. Rez. Przyr. 31:11-20.

Pearson RG, Jones NV, 1975. The effects of dredging operations on the benthic community of a chalk stream. Biol. Conserv. 8:273-278.

Phelps HL, 2001. Biomonitoring Anacostia River Estuary pollutants with the Asiatic clam (Corbicula fluminea): Possible effects of dredging. Final Technical Report to the District Columbia Water Resources Research Center.

Ribera I, Vogler AP, 1999. Habitat type as a determinant of species range sizes: the example of lotic-lentic differences in aquatic Coleoptera. Biol. J. Linnean Soc. 71:33-52.

Richoux P, 1994. Theoretical habitat templets, species traits, and species richness: aquatic Coleoptera in the Upper Rhône River and its floodplain. Freshwater Biol. 31:377-395.

Rincón PA, Lobón-Cerviá J, 1997. Temporal patterns in macroinvertebrate drift in a northern Spanish stream. Mar. Freshwater Res. 48:455-464.

Sanderson RA, Eyre MD, Rushton SP, 2005. The influence of stream invertebrate composition at neighbouring sites on local assemblage composition. Freshw. Biol. 50:221-231.

Sarr AB, Benetti CJ, Fernández-Díaz M, Garrido J, 2013. The microhabitat preferences of water beetles in four rivers in Ourense province, Northwest Spain. Limnetica 32:1-10.

Sertić Perić M, Dražina T, Špoljar M, Radanović I, Primc B, Habdija I, 2014. Meiofauna constitute a considerable portion of invertebrate drift among moss-rich patches within a karst hydrosystem. Biologia 69:363-380.

Skilleter GA, 2002. Structure of macrobenthic communities in relation to historical patterns of dredging in the Brisbane River estuary. Proc. Royal Soc. Queensland 110:75-83.

Smith EP, Orvos DR, Cairns J Jr, 1993. Impact assessment using the before-after-control-impact (BACI) model: concerns and comments. Can. J. Fish. Aquat. Sci. 50:627-637.

Stępień E, Zawal A, Buczyńska E, Buczyński P, (2015a). Effects of dredging on the vegetation in small lowland river. Limnetica (In press).

Stępień E, Zawal A, Buczyńska E, Buczyński P, 2015b. Changes in plant communities in the regulated river on the example of Krąpiel river. Acta Biologica 22:167-196.
Svendsen KM, Renshaw CE, Magilligan FJ, Nislow KH, Kaste JM, 2009. Flow and sediment regimes et tributary junctions on a regulated river: impact on sediment residence time and benthic macroinvertebrate communities. Hydrol. Process. 23:284-296.

Szlauer-Łukaszewska A, Zawal A, 2014. The impact of river dredging on ostracod assemblages in the Krąpiel River (NW Poland). Fundam. Appl. Limnol. 185:295-305.

ter Braak CJF, 1986. Canonical correspondence analysis: a new eigenvector technique for multivariate direct gradient analysis. Ecology 67:1167-1179.

ter Braak CJF, Verdonschot PFM, 1995. Canonical correspondence analysis and related multivariate methods in aquatic ecology. Aquat. Sci. 57:255-289.

Wichtowska M, Sobczak A, 1994. Formation of the water beetle (Coleoptera) fauna in conditions of the urban agglomeration of Szczecin (Western Pomerania). Acta Hydrobiol. 36:57-74.

Wilber DH, Clark DG, 2007. Defining and assessing benthic recovery following dredging and dredged material disposal, p. 603-618. In: R.E. Randall (ed.), Proceedings of the XVIII World Dredging Congr., Lake Buena Vista, FL, USA. Newman Printing Co., Bryan.

Williams P, Whitfield M, Biggs J, Bray S, Fox G, Nicolet P, Sear D, 2003. Comparative biodiversity of rivers, streams, ditches and ponds in an agricultural landscape in Southern England. Biol. Conserv. 115:329-341.

van Dolah RF, Calder DR, Knott DM, 1984. Effects of dredging and open-water disposal on benthic macroinvertebrates in a South Carolina estuary. Estuaries 7:28-37.

Yount JD, Niemi GJ, 1990. Recovery of lotic communities and ecosystems from disturbance - A narrative review of case studies. Environ. Manage. 14:547-569.

Zawal A, Czachorowski S, Stępień E, Szlauer-Łukaszewska A, Buczyńska E, Buczyński P, Stryjecki R, Dąbkowski P, 2016a. Early post-dredging recolonization of caddisflies (Insecta: Trichoptera) in a small lowland river (NW Poland). Limnology 17:71-85.

Zawal A, Dzierzgowska K, Szlauer-Łukaszewska A, Michoński G, Kłosowska M, Bańkowska A, Stryjecki R, 2013. A thermocline as an obstacle to the spread of water mites (Acari: Hydrachnidia) across the lake profile. Aquat. Insect. 35:47-61.

Zawal A, Stępień E, Szlauer-Łukaszewska A, Michoński G, Kłosowska M, Bańkowska A, Myśliwy M, Stryjecki R, Buczyńska E, Buczyński P, 2015. The influence of dredging of a lowland river (the Krapiel in NW Poland) on water mite fauna (Acari: Hydrachnidia). Fundam. Appl. Limnol. 186:217-223.

Zawal A, Sulikowska-Drozd A, Stępień E, Szlauer-Łukaszewska A, Jankowiak $Ł, 2016 \mathrm{~b}$. Regeneration of the molluscan fauna of a small lowland river after dredging. Fundam. Appl. Limnol. 187:281-293. 